\title{
Lithium Enhances Muscarinic Receptor-Stimulated CDP-Diacylglycerol Formation in Inositol-Depleted SK-N-SH Neuroblastoma Cells
}

\author{
Evan B. Stubbs, Jr. and Bernard W. Agranoff \\ Departments of Biological Chemistry and Psychiatry and Mental Health Research Institute, \\ University of Michigan, Ann Arbor, Michigan, U.S.A.
}

\begin{abstract}
The psychotherapeutic action of $\mathrm{Li}^{+}$in brain has been proposed to result from the depletion of cellular inositol secondary to its block of inositol monophosphatase. This action is thought to slow phosphoinositide resynthesis, thereby attenuating stimulated phosphoinositidase-mediated signal transduction in affected cells. In the present study, the effect of $\mathrm{Li}^{+}$on muscarinic receptor-stimulated formation of the immediate precursor of phosphatidylinositol, CDP-diacylglycerol (CDP-DAG), has been examined in human SK-N-SH neuroblastoma cells that have been cultured under conditions that alter the cellular content of myo-inositol. Resting neuroblastoma cells, like brain cells in vivo, were found to concentrate inositol from the culture medium, achieving an intracellular level of $60.0 \pm 4 \mathrm{nmol} /$ $\mathrm{mg}$ of protein. The addition of carbachol to $\left[{ }^{3} \mathrm{H}\right]$ cytidineprelabeled cells elicited a four- to fivefold increase in the accumulation of labeled CDP-DAG. This stimulated formation of $\left[{ }^{3} \mathrm{H}\right] \mathrm{CDP}-\mathrm{DAG}$ was completely blocked by the addition of $10 \mu \mathrm{M}$ atropine, was not dependent on the presence of $\mathrm{Li}^{+}$, nor was it affected by co-incubation with myoinositol. This result was in sharp contrast to findings in rat brain slices, in which carbachol-stimulated formation of $\left[{ }^{3} \mathrm{H}\right] \mathrm{CDP}-\mathrm{DAG}$ was potentiated $\sim 10$-fold by $\mathrm{Li}^{+}$and substantially reduced by coincubation with inositol. The formation of $\left[{ }^{3} \mathrm{H}\right] \mathrm{CDP}-\mathrm{DAG}$ in labeled SK-N-SH cells by carbachol was both concentration and time dependent. The
\end{abstract}

order of efficacy of muscarinic ligands in stimulating $\left[{ }^{3} \mathrm{H}\right]$ CDP-DAG accumulation paralleled that established in these cells for inositol phosphate accumulation, i.e., carbachol $\geq$ oxotremorine- $M>$ bethanecol $\geq$ arecoline $>$ oxotremorine $>$ pilocarpine. Extended culture of the SK-N-SH cells in an inositol-free chemically defined growth medium progressively reduced the intracellular inositol content to $<5 \mathrm{nmol} / \mathrm{mg}$ of protein, a level comparable with that seen in cortical slices. In these inositol-depleted cells, $\mathrm{Li}^{+}$potentiated carbachol-stimulated $\left[{ }^{3} \mathrm{H}\right] \mathrm{CDP}-D A G$ formation, and this effect was completely reversed by coincubation with inositol $\left(\mathrm{EC}_{50} 0.2 \mathrm{~m} M\right)$. The present study thus demonstrates, in the same cultured cell line, the effects of normal and reduced intracellular inositol levels on the ability of $\mathrm{Li}^{+}$ to attenuate phosphoinositide resynthesis, as inferred from $\left[{ }^{3} \mathrm{H}\right]$ CDP-DAG accumulation. The results indicate that $\mathrm{Li}^{+}$ can lead to a slowing of stimulated phosphoinositide turnover in neuroblastoma cells, provided that the intracellular inositol content has been significantly reduced. Key Words: CDP-diacylglycerol-Inositol-Lithium-MuscarinicNeuroblastoma--Phosphoinositides. Stubbs E. B. Jr. and Agranoff B. W. Lithium enhances muscarinic receptorstimulated CDP-diacylglycerol formation in inositol-depleted SK-N-SH neuroblastoma cells. J. Neurochem. 60, 1292-1299 (1993).
Lithium $\left(\mathrm{Li}^{+}\right)$is widely used in the treatment of manic-depressive disorders, although the molecular basis of its therapeutic action remains unclear. The possibility of a postreceptor site of action was suggested from earlier studies reporting an inhibition of stimulated adenylate cyclase activity by $\mathrm{Li}^{+}$in several tissues, including brain (Forn and Valdecasas, 1971; Ebstein et al., 1980). Attenuation of the phosphoino- sitidase-mediated signal transduction pathway by $\mathrm{Li}^{+}$, a potent uncompetitive inhibitor of inositol monophosphatase (Hallcher and Sherman, 1980), was suggested by a number of studies (Allison and Stewart, 1971; Allison et al., 1976; Sherman et al., 1981, 1985) that demonstrated a large accumulation of inositol monophosphates concomitant with a reduction in inositol content after CNS receptor activation. That
Received April 15, 1992; revised manuscript received August 5, 1992; accepted September 8, 1992.

Address correspondence and reprint requests to Dr. B. W. Agranoff at Neuroscience Laboratory Building, University of Michigan, 1103 East Huron, Ann Arbor, MI 48104-1687, U.S.A.
Abbreviations used: CDP-DAG, CDP-diacylglycerol; IFCD, inositol-free chemically defined; PI, phosphatidylinositol; PIP $_{2}$, phosphatidylinositol 4,5-bisphosphate. 
inhibition of inositol monophosphatase by $\mathrm{Li}^{+}$may result in the depletion of intracellular inositol content, and thereby interrupt the resynthesis of phosphoinositides (Sherman et al., 1981; Berridge et al., 1982), is particularly relevant to the CNS because inositol cannot be readily replenished from the periphery due to the selective permeability of the blood-brain barrier. Recent studies using cerebral cortex slices have demonstrated inhibitory effects of $\mathrm{Li}^{+}$on muscarinic stimulated inositol tris- and tetrakisphosphate accumulation (Whitworth and Kendall, 1988; Kennedy et al., 1989, 1990), an effect that is shown in some cases to be reduced by coincubation with inositol. However, the inability of $\mathrm{Li}^{+}$to reduce levels of phosphatidylinositol 4,5-bisphosphate $\left(\mathrm{PIP}_{2}\right)$ in treated tissue (Drummond and Raeburn, 1984; Downes and Stone, 1986; Honchar et al., 1989) complicates the inositol depletion model. A multiplicity of the effects of $\mathrm{Li}^{+}$on several enzymes of the inositol phosphate cycle (Inhorn and Majerus, 1987; Gee et al., 1988) and alternate mechanisms including other postreceptor sites (Wood and Goodwin, 1987; Godfrey et al., 1989; Avissar et al., 1988, 1991) are now recognized.

More direct evidence for an effect of $\mathrm{Li}^{+}$on the phosphoinositidase-mediated second messenger system has been obtained by measuring agonist-induced formation of CDP-diacylglycerol (CDP-DAG), the immediate precursor of phosphatidylinositol (PI), in brain slices (Godfrey, 1989; Kennedy et al., 1990). Although this effect by $\mathrm{Li}^{+}$on CDP-DAG accumulation has also been observed in parotid gland slices (Downes and Stone, 1986), human platelets (Watson et al., 1990), and human neutrophils (Stubbs et al., 1992), it could not be demonstrated in cultured cells (Drummond and Raeburn, 1984). The response to $\mathrm{Li}^{+}$in these various cell preparations might be explained on the basis of differences in endogenous inositol levels. The present study was therefore undertaken to examine the effect of $\mathrm{Li}^{+}$on muscarinic agonist stimulation of CDP-DAG in cultured human SK-N-SH neuroblastoma cells grown under conditions that modulate intracellular inositol content. A preliminary report of this study has appeared in abstract form (Stubbs et al., 1991).

\section{MATERIALS AND METHODS}

Human SK-N-SH neuroblastoma cells of the neuroblast phenotype were cultured at $37^{\circ} \mathrm{C}$ in a humidified atmosphere ( $10 \% \mathrm{CO}_{2} / 90 \%$ air) in Dulbecco's modified Eagle's medium supplemented with $10 \%$ fetal bovine serum (GIBCO BRL, Grand Island, NY, U.S.A.). Where specified, SK-N-SH cells were cultured in an inositol-free chemically defined (IFCD) growth medium (Bottenstein and Sato, 1979), which was changed daily for 5-7 days for the purpose of depleting cellular inositol. Adolescent (13-18 days) rats were killed by decapitation and the cerebral cortex was dissected, cross-chopped with a McIlwain tissue chopper (350 $\times 350 \mu \mathrm{m})$, and slices were washed as described previously
(Heacock et al., 1987). SK-N-SH cells grown to confluency (7-10 days) were harvested with Puck's $D_{1}$ solution, washed once with buffer A containing $(\mathrm{m} M) \mathrm{NaCl} 142, \mathrm{KCl} 5.4$, $\mathrm{NaHCO}_{3} 3.6, \mathrm{CaCl}_{2} 2.2, \mathrm{MgCl}_{2}$ 1.0, D-glucose 5.6, and HEPES 30, pH 7.4, saturated with $\mathrm{O}_{2} / \mathrm{CO}_{2}(19: 1$, vol/vol), and suspended at a concentration of $1-2 \mathrm{mg}$ of protein $/ \mathrm{ml}$. Gravity-packed slices $(50 \mu \mathrm{l})$ or suspended cells $(\sim 0.3 \mathrm{mg}$ of protein), in a final volume of $500 \mu \mathrm{l}$, were incubated in flat-bottomed polypropylene minivials in the presence of $\left[{ }^{3} \mathrm{H}\right]$ cytidine (specific activity $25 \mathrm{Ci} / \mathrm{mmol}, 3 \mu \mathrm{Ci}$ per minivial; Sigma Chemical Co., St. Louis, MO, U.S.A.) for 60 min at $37^{\circ} \mathrm{C}$ followed by stimulation with either buffer $\mathrm{A}$ or a muscarinic agonist for $30-60 \mathrm{~min}$. Reactions were quenched by the addition of $1.5 \mathrm{ml}$ of chloroform/methanol $(1: 2, \mathrm{vol} / \mathrm{vol})$, and labeled lipids were extracted from the lower phase formed upon the addition of $0.5 \mathrm{ml}$ of $\mathrm{HCl}(1.2$ $M$ ) and $1.0 \mathrm{ml}$ of chloroform. After phase separation by low-speed centrifugation, a portion of the resultant lower phase was washed twice with acidified methanol containing $2.5 \mathrm{~m} M$ cytidine (Sigma) and $\left[{ }^{3} \mathrm{H}\right] \mathrm{CDP}-\mathrm{DAG}$ was identified by TLC on oxalate-impregnated silica gel 60 plates developed in chloroform/acetone/methanol/acetic acid/water (40:15:13:12:8, by vol). The radiolabeled band comigrating with authentic CDP-DAG standard (see Fig. 1) was scraped and counted. Alternatively, a fraction of the acid-washed organic phase was dried and counted by scintillation spectrometry.

Cellular inositol was quantitated by a modification of the acetylation method of Mount and Laker (1981). In brief, prepared cells or cortical slices $(\sim 1 \mathrm{mg}$ of protein each) were suspended in a total volume of $1 \mathrm{ml}$ with distilled water in the presence of $50 \mu \mathrm{g}$ of xylitol internal standard (Sigma). Cells or tissue slices were disrupted with $1.5 \mathrm{ml}$ of chloroform/methanol $(1: 2, \mathrm{vol} / \mathrm{vol})$ and were vortexed vigorously, followed by the addition of $1.0 \mathrm{ml}$ of chloroform. After phase separation by low-speed centrifugation, the upper aqueous phase was dried overnight in vacuo and then stored for at least $1 \mathrm{~h}$ over phosphorus pentoxide. Samples were acetylated by incubating at $70^{\circ} \mathrm{C}$ for $30 \mathrm{~min}$ in $0.5 \mathrm{ml}$ of pyridine (previously refluxed for $30 \mathrm{~min}$ over potassium hydroxide and redistilled) followed by the addition of $0.5 \mathrm{ml}$ of acetic anhydride for an additional $10 \mathrm{~min}$ at $70^{\circ} \mathrm{C}$. Acetylated samples were dried and stored as described above before separation on an SP2330 capillary column (Supelco, Bellefonte, PA, U.S.A.) using a Hewlett Packard 5890A gas chromatograph programmed with an isothermal oven temperature at $200^{\circ} \mathrm{C}$ for the first 2 min followed by a linear ramp up to $250^{\circ} \mathrm{C}$, rising at a rate of $4^{\circ} \mathrm{C} / \mathrm{min}$, and sustained for an additional $16 \mathrm{~min}$. Peaks were quantitated with a Hewlett Packard 3396A integrator. Under these conditions, acetylated inositol chromatographed free of glucose anomers and eluted as a single peak with a retention time of $23.5 \mathrm{~min}$.

\section{RESULTS}

\section{Muscarinic receptor-stimulated formation of $\left[{ }^{3} \mathrm{H}\right]-$ CDP-DAG}

The addition of carbachol $(10 \mathrm{mM})$ to $\left[{ }^{3} \mathrm{H}\right]-$ cytidine-prelabeled SK-N-SH neuroblastoma cells resulted in a three- to fivefold increase of a single ${ }^{3} \mathrm{H}$ lipid-soluble substance that, when separated by TLC (Fig. 1), comigrated with authentic CDP-dipalmitin and with CDP-DAG prepared from egg lecithin $\left(R_{\mathrm{f}}\right.$ 


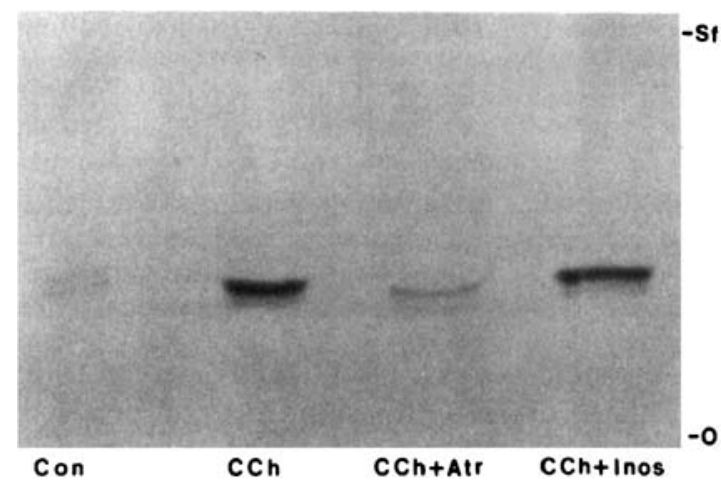

FIG. 1. Autoradiogram of $\left[{ }^{3} \mathrm{H}\right]$ cytidine-labeled lipids extracted from SK-N-SH neuroblastoma. Cells $(0.4 \mathrm{mg}$ of protein) were prelabeled with $\left[{ }^{3} \mathrm{H}\right]$ cytidine $(6 \mu \mathrm{Ci} / \mathrm{ml})$ for $60 \mathrm{~min}$ at $37^{\circ} \mathrm{C}$ and subsequently treated with buffer $A$ (control; Con), $10 \mathrm{mM}$ carbachol (CCh), $10 \mathrm{mM}$ carbachol $+10 \mu \mathrm{M}$ atropine (CCh + Atr), or $10 \mathrm{mM}$ carbachol $+10 \mathrm{mM}$ inositol (CCh + Inos), as indicated, for an additional $30 \mathrm{~min}$. Lipids were extracted and separated as described in Materials and Methods. O, origin; Sf, solvent front.

$=0.43)$. A qualitatively similar autoradiographic profile was observed when $\left[{ }^{3} \mathrm{H}\right]$ cytidine-prelabeled cortical slices were stimulated with $1 \mathrm{~m} M$ carbachol (data not shown). As has been previously observed, carbachol or $\mathrm{Li}^{+}$alone had no effect on CDP-DAG accumulation, whereas the combination produced pronounced enhancement (Godfrey, 1989). In contrast to results from experiments with cortical slices, the stimulated formation of $\left[{ }^{3} \mathrm{H}\right] \mathrm{CDP}-\mathrm{DAG}$ in cultured cells was independent of $\mathrm{Li}^{+}$and was found to be insensitive to the presence of inositol (Table 1). This stimulated production of $\left[{ }^{3} \mathrm{H}\right] \mathrm{CDP}-\mathrm{DAG}$ in SK-NSH cells was time and concentration dependent. There was a fivefold increase in $\left[{ }^{3} \mathrm{H}\right] \mathrm{CDP}-\mathrm{DAG}$ accumulation, which reached asymptote within $10 \mathrm{~min}$ of carbachol addition and was sustained for at least 30 min (Fig. 2). In parallel incubations, the addition of $10 \mu M$ atropine to carbachol-stimulated cells caused a rapid depletion of $\left[{ }^{3} \mathrm{H}\right] \mathrm{CDP}-\mathrm{DAG}$, suggesting metabolism of newly synthesized CDP-DAG subsequent to muscarinic receptor blockade. The $\mathrm{Li}^{+}$-independent formation of $\left[{ }^{3} \mathrm{H}\right] \mathrm{CDP}-\mathrm{DAG}$ was observed at carba- chol concentrations as low as $1 \mu M$ and was maximal at $1 \mathrm{~m} M$ with a half-maximal accumulation at 7.5 $\pm 0.5 \mu M$ (Fig. 3). The selectivity of muscarinic agonists in stimulating $\left[{ }^{3} \mathrm{H}\right] \mathrm{CDP}-\mathrm{DAG}$ formation agreed well with the known efficacy of these agents in initiating phosphoinositide turnover in SK-N-SH cells (Fisher and Snider, 1987). In three separate experiments, the full muscarinic agonist oxotremorine-M ( 1 $\mathrm{m} M$ ) was as effective at eliciting $\left[{ }^{3} \mathrm{H}\right] \mathrm{CDP}-\mathrm{DAG}$ formation $(90 \pm 6 \%)$ as $1 \mathrm{~m} M$ carbachol, whereas equimolar concentrations of partial muscarinic agonists were less effective; thus, bethanechol $(74 \pm 3 \%)=$ arecoline $(73 \pm 4 \%)>$ oxotremorine $(63 \pm 1 \%)>$ pilocarpine $(44 \pm 3 \%)$.

\section{Intracellular inositol content}

The inositol content of freshly cut cortical slices of adolescent rat brain was found to be $21 \pm 0.9 \mathrm{nmol} /$ $\mathrm{mg}$ of protein $(\mathrm{n}=6)$, the same as is found in cortical samples taken directly from the brain shortly after decapitation $(21.1 \pm 1.7 \mathrm{nmol} / \mathrm{mg}$ of protein; $\mathbf{n}=3)$. After the washing procedure, the inositol content of the slices was reduced to $8.9 \pm 0.4 \mathrm{nmol} / \mathrm{mg}$ of protein ( $\mathrm{n}=6, p<0.001)$, or $\sim 0.9 \mathrm{mM}$, well below the reported $K_{\mathrm{m}}(4.6 \mathrm{~m} M$ inositol) for rat brain PI synthase (Ghalayini and Eichberg, 1985). This $60 \%$ reduction in cellular inositol content may thus slow PI synthase on the basis of substrate limitation, resulting in the accumulation of lipid precursors of the phosphoinositide cycle such as DAG, DAG-phosphate (phosphatidate), and/or CDP-DAG. In contrast to cortical slices, the inositol content in washed SK-N-SH cells was found to be $60.0 \pm 4.0 \mathrm{nmol} / \mathrm{mg}$ of protein $(\mathrm{n}=8)$. This more closely approximates the value we found in the adult rat cortex, $48.5 \pm 1.5 \mathrm{nmol} / \mathrm{mg}$ of protein $(\mathrm{n}$ $=6$ ), a notably higher value than we observed in adolescent rat brain. These data suggest that the stimulated formation of $\left[{ }^{3} \mathrm{H}\right] \mathrm{CDP}-D A G$ in SK-N-SH cells cultured in standard growth medium does not result from a deficit of cellular inositol, in contrast to what may well be the case in studies with prewashed cortical brain slices incubated in the presence of $\mathrm{Li}^{+}$(Godfrey, 1989; Kennedy et al., 1990; Table 1).

TABLE 1. The effect of $\mathrm{LiCl}$ and myo-inositol on $\left.{ }^{3} \mathrm{H}\right] \mathrm{CDP} \cdot \mathrm{DAG}$ formation in human SK-N-SH neuroblastoma cells and cerebral cortex slices

\begin{tabular}{lccccc}
\hline & \multicolumn{2}{c}{ SK-N-SH } & & \multicolumn{2}{c}{ Cortical slices } \\
\cline { 2 - 3 } \cline { 6 - 6 } & Basal & Carbachol & & Basal & Carbachol \\
\hline Control & $314 \pm 47$ & $1,624 \pm 82$ & & 6,890 & 6,150 \\
$\mathrm{LiCl}$ & $307 \pm 60$ & $1,748 \pm 48$ & & $6,908 \pm 475$ & $68,700 \pm 3,231$ \\
$\mathrm{LiCl}+$ inositol & $278 \pm 51$ & $1,533 \pm 45$ & & $1,755 \pm 88$ & $11,660 \pm 1,662$ \\
\hline
\end{tabular}

$\left[{ }^{3} \mathrm{H}\right]$ Cytidine-prelabeled cells $(0.3-0.35 \mathrm{mg}$ of protein) or 13-18-day-old-rat cortical slices (1 $\mathrm{mg}$ of protein) were treated with buffer (control) and $10 \mathrm{mM} \mathrm{LiCl}$ with or without $10 \mathrm{~m} M$ inositol as indicated, followed by incubation with carbachol for an additional $30 \mathrm{~min}$ (cells) or 60 min (slices). Data shown (dpm) are the means \pm SEM for separate SK-N-SH cell $(n=3)$ and cortical slice $(n=5)$ preparations. Control values for cortical slices are the average of duplicates. 


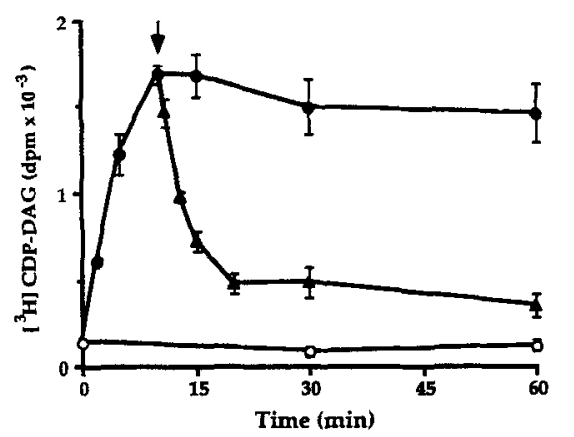

FIG. 2. Time-dependent, atropine reversible, accumulation of $\left[{ }^{3} \mathrm{H}\right] \mathrm{CDP}-\mathrm{DAG}$ in carbachol-stimulated SK-N-SH neuroblastoma cells. $\left.{ }^{3} \mathrm{H}\right]$ Cytidine-prelabeled cells $(0.35 \mathrm{mg}$ of protein) were treated with buffer (open circles) or $10 \mathrm{mM}$ carbachol (closed circles) for the duration of time indicated. Parallel incubations received $10 \mu \mathrm{M}$ atropine (arrow) $10 \mathrm{~min}$ after the addition of carbachol (triangles). Data shown are the means \pm SEM from three experiments each performed in duplicate. See also Fig. 8.

\section{Potentiation by $\mathrm{Li}^{+}$of stimulated $\left.\left.\right|^{3} \mathrm{H}\right] \mathrm{CDP}-\mathrm{DAG}$ formation and reversal with inositol}

Treatment of SK-N-SH cells with $10 \mathrm{mM} \mathrm{LiCl}$ in culture for $48 \mathrm{~h}$ did not affect the intracellular content of inositol. At longer times in culture, indications of cellular toxicity became manifest. However, when SK-N-SH cells were cultured in an IFCD growth medium, a time-dependent reduction of intracellular inositol was observed (Fig. 4), without detectable effects on cell viability, as determined by trypan blue dye exclusion. By day 5, cellular inositol content was reduced by $>90 \%$, to $5.5 \pm 0.5 \mathrm{nmol} / \mathrm{mg}$ of protein (n $=5$ ). Cells appeared viable for longer time periods, but further reductions in cellular inositol were not seen. Prestimulation of IFCD-cultured SK-N-SH cells with $1 \mathrm{~m} M$ carbachol for $120 \mathrm{~min}$ in the presence of 1 $\mathrm{m} M \mathrm{LiCl}$ further reduced the intracellular content of

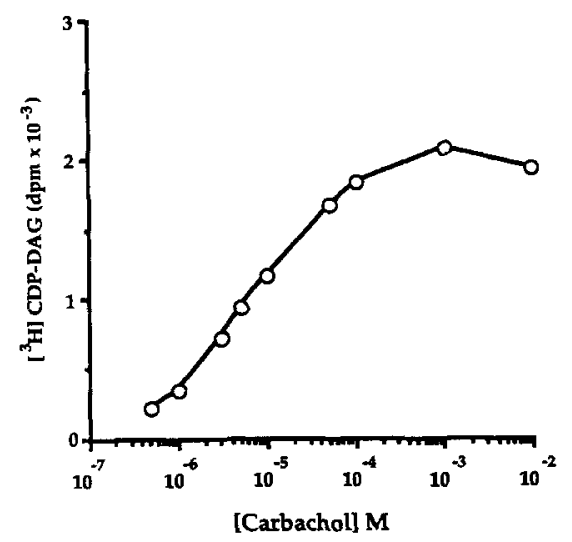

FIG. 3. Concentration-dependent stimulation of $\left[{ }^{3} \mathrm{H}\right] \mathrm{CDP}-\mathrm{DAG}$ formation by carbachol in SK-N-SH cells. $\left.{ }^{3} \mathrm{H}\right]$ Cytidine-prelabeled cells $(0.35 \mathrm{mg}$ of protein) were treated with the indicated concentrations of carbachol for $30 \mathrm{~min}$ at $37^{\circ} \mathrm{C}$. $\left[{ }^{3} \mathrm{H}\right] \mathrm{CDP}-D A G$ was extracted and quantitated as described in the legend of Fig. 1. The data shown are the means from three experiments, variance $<5 \%$. An $\mathrm{EC}_{50}$ of $7.5 \pm 0.5 \mu \mathrm{M}$ was determined from probit analysis of the data.

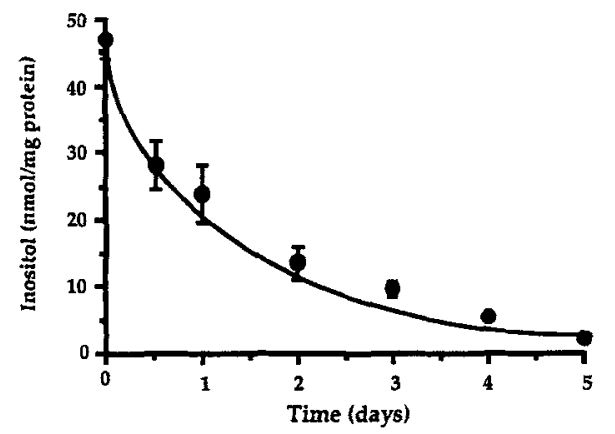

FIG. 4. Time-dependent reduction of myo-inositol content in SK$\mathrm{N}-\mathrm{SH}$ neuroblastoma cells. Log-phase cells were cultured in an IFCD growth medium as described in the text for the number of days indicated and analyzed for inositol content as described in Materials and Methods. Data shown are the means \pm SD of quadruplicate determinations from a single experiment.

inositol to $<1 \mathrm{nmol} / \mathrm{mg}$ of protein. A comparison of the effect of $\mathrm{Li}^{+}$on carbachol-stimulated $\left.{ }^{3} \mathrm{H}\right] \mathrm{CDP}$ DAG formation in IFCD-cultured cells before and after agonist pretreatment is shown in Fig. 5. It can be seen that basal accumulation of $\left[{ }^{3} \mathrm{H}\right] \mathrm{CDP}-\mathrm{DAG}$ is elevated in IFCD cells, reflecting a slowing of PI synthesis. When assayed in the absence of $\mathrm{Li}^{+}$, carbachol stimulated a small (52\%), but significant, increase in $\left[{ }^{3} \mathrm{H}\right] \mathrm{CDP}-\mathrm{DAG}$ formation (Fig. 5A). Inclusion of 1 $\mathrm{m} M \mathrm{Li}^{+}$to the incubation assay resulted in a greater than twofold increase in the stimulated formation of $\left[{ }^{3} \mathrm{H}\right]$ CDP-DAG (Fig. 5B). Prior treatment of IFCDcultured cells with carbachol $+\mathrm{LiCl}(1 \mathrm{~m} M$ each) resulted in a maximal fourfold increase in subsequent carbachol-stimulated $\left[{ }^{3} \mathrm{H}\right] \mathrm{CDP}-\mathrm{DAG}$ formation (Fig. $5 \mathrm{C})$. In each case, coincubation with inositol ( $10 \mathrm{mM})$ completely reversed the stimulated formation of $\left[{ }^{3} \mathrm{H}\right]-$ CDP-DAG (Fig. 5), suggesting that under these conditions, the accumulation of CDP-DAG resulted from inositol-substrate limitation of PI synthase and that therapeutic concentrations of $\mathrm{Li}^{+}$further exacerbated this limitation. This effect by $\mathrm{Li}^{+}$on $\left[{ }^{3} \mathrm{H}\right] \mathrm{CDP}-\mathrm{DAG}$ formation was maximally effective at $10 \mathrm{~m} M$ with an $\mathrm{EC}_{50}$ of $2.6 \pm 0.3 \mathrm{~m} M$ (Fig. 6). At concentrations as low as $50 \mu M$, inositol reduced this potentiation by $\mathrm{Li}^{+}$, was maximal at $10 \mathrm{~m} M$, and exhibited a halfmaximal effect at $0.20 \pm 0.03 \mathrm{mM}$ (Fig. 7).

To further investigate the nature of the atropine effect on $\left[{ }^{3} \mathrm{H}\right] \mathrm{CDP}-\mathrm{DAG}$ accumulation, the experiment described in Fig. 2 was repeated in inositol-depleted cells. Under these conditions, a linear accumulation of $\left[{ }^{3} \mathrm{H}\right] \mathrm{CDP}-\mathrm{DAG}$ was seen after addition of carbachol for $15 \mathrm{~min}$, which then increased at later times. Atropine addition again resulted in a loss of labeled liponucleotide (Fig. 8).

\section{DISCUSSION}

It has been amply demonstrated that after preincubation with $\left[{ }^{3} \mathrm{H}\right]$ inositol, the addition of an appropriate ligand such as carbachol in the presence of $\mathrm{Li}^{+}$ 

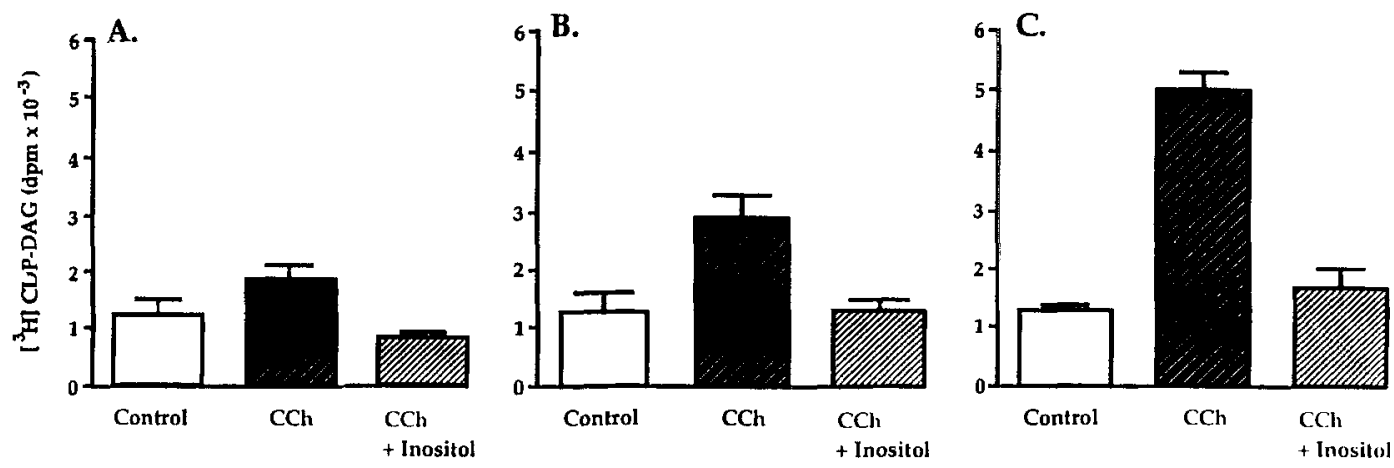

FIG. 5. Stimulated accumulation of $\left[{ }^{3} \mathrm{H}\right]$ CDP-DAG by carbachol in inositol-deficient SK-N-SH cells: potentiation by $\mathrm{Li}^{+}$and reversal with myo-inositol. Cells were cultured for 6-7 days in an IFCD growth medium and prestimulated with buffer (A, B) or $1 \mathrm{mM}$ carbachol/1 mM $\mathrm{LiCl}(\mathrm{C})$ for $2-4 \mathrm{~h}$ before harvest. Harvested cells $\left(0.3 \mathrm{mg}\right.$ of protein) were then prelabeled for $60 \mathrm{~min}$ with [ ${ }^{3} \mathrm{H}$ ]cytidine in the absence (A) or presence (B, C) of $1 \mathrm{mM} \mathrm{LiCl}$ and stimulated for an additional $30 \mathrm{~min}$ with either buffer (control), $1 \mathrm{~m} M$ carbachol (CCh), or $1 \mathrm{mM}$ carbachol in the presence of $10 \mathrm{mM}$ inositol (CCh + Inositol), as indicated. Data shown are the means \pm SEM from three to five experiments. The cellular content of inositol before prestimulation was $7 \mathrm{nmol} / \mathrm{mg}$ of protein. Prestimulation with carbachol in the presence of $\mathrm{Li}^{+}$further reduced the cellular content of inositol below detectable levels $(<1 \mathrm{nmol} / \mathrm{mg}$ of protein).

to a tissue slice or cultured cell incubation medium results in a pronounced accumulation of labeled inositol phosphates (see Fisher et al., 1992). Although it is evident that this accumulation is attributable to the uncompetitive inhibition of inositol monophosphatase by $\mathrm{Li}^{+}$(Hallcher and Sherman, 1980), it is less clear that this action of $\mathrm{Li}^{+}$can also explain its wellknown beneficial actions in the treatment of psychoses. The inositol depletion hypothesis for the psychotherapeutic action of $\mathrm{Li}^{+}$proposes that the block of inositol monophosphatase creates a shortage of inositol as substrate for the regeneration of phosphoinositides via PI synthase, and that this effect of $\mathrm{Li}^{+}$is especially profound in those cells that have been most heavily stimulated (Berridge et al., 1982). Reversal by inositol of a $\mathrm{Li}^{+}$-mediated decrease of inositol polyphosphates in tissue slices (Whitworth and Kendall, 1988; Kennedy et al., 1989, 1990) appears to support

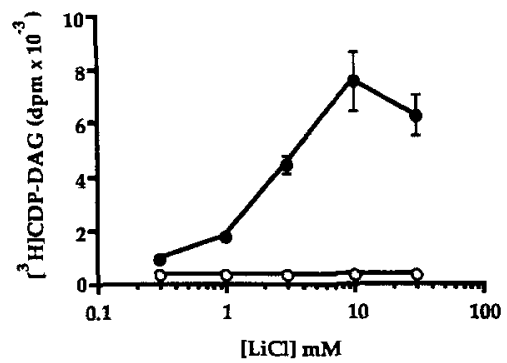

FIG. 6. Concentration-dependent accumulation of $\left[{ }^{3} \mathrm{H}\right] \mathrm{CDP}-\mathrm{DAG}$ by $\mathrm{Li}^{+}$in carbachol-stimulated inositol-deficient SK-N-SH cells. Cells ( $0.3 \mathrm{mg}$ of protein), previously cultured for 7 days in an IFCD growth medium, were prelabeled with $\left[{ }^{3} \mathrm{H}\right]$ cytidine for $50 \mathrm{~min}$, treated with the indicated concentration of $\mathrm{LiCl}$ for an additional $10 \mathrm{~min}$, and stimulated with $1 \mathrm{mM}$ carbachol (closed circles) or buffer (open circles) for an additional $30 \mathrm{~min}$. The inositol content of conditioned cells was $3 \mathrm{nmol} / \mathrm{mg}$ of protein. Data shown are the means \pm SEM from three cell preparations. Variance was less than symbol size where error bars are absent. the hypothesis. Further support comes from recent in vivo evidence (Sun et al., 1992) that $\mathrm{Li}^{+}$increases inositol phosphates, based on chemical mass determinations and labeled inositol incorporation. On the other hand, Whitworth et al. (1990) suggested that both chronic and acute $\mathrm{Li}^{+}$treatment in vivo may actually enhance stimulated phosphoinositide turnover in brain. Sillence and Downes (1992) recently reported that both chemical amounts and labeling of the inositol phosphates were increased in $\mathrm{Li}^{+}$-treated tissue slices, but that increases seen in inositol phosphate mass were much less than labeling might otherwise indicate.

A major concern regarding the relevance of the inositol depletion hypothesis for the nervous system is the high content of inositol in the brain, and the relatively small decreases that are produced by chronic, or even by high acute doses of $\mathrm{Li}^{+}$in experimental ani-

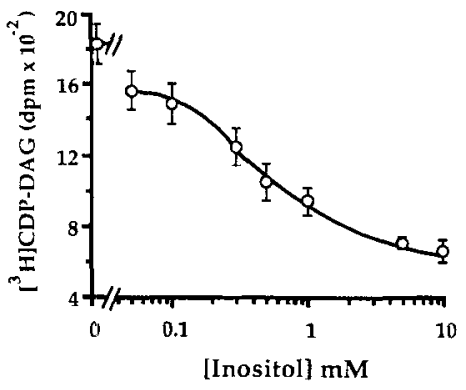

FIG. 7. Reversal of carbachol-stimulated $\left.{ }^{3} \mathrm{H}\right] \mathrm{CDP}-\mathrm{DAG}$ accumulation by myo-inositol in conditioned SK-N-SH cells. Cells $(0.3 \mathrm{mg}$ of protein), previously cultured for 8 days in an IFCD growth medium, were prelabeled with $\left[{ }^{3} \mathrm{H}\right]$ cytidine for $50 \mathrm{~min}$ in the presence of $1 \mathrm{mM} \mathrm{LiCl}$, treated with the indicated concentrations of inositol for an additional $10 \mathrm{~min}$, and stimulated with carbachol $(1 \mathrm{mM})$ for an additional $30 \mathrm{~min}$. The inositol content of conditioned cells was $6 \mathrm{nmol} / \mathrm{mg}$ of protein. Data shown are the means \pm SEM from three cell preparations. 


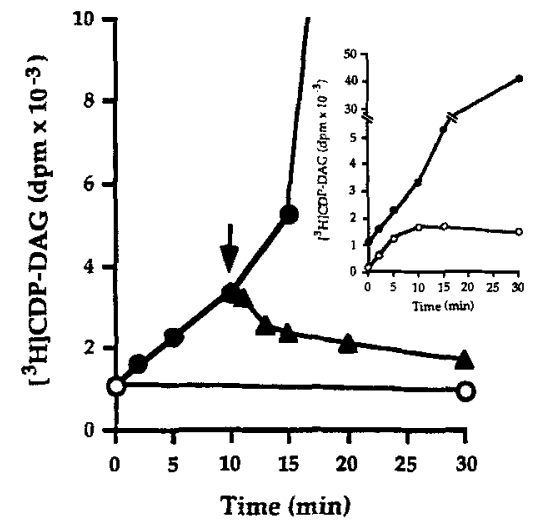

FIG. 8. Time-dependent, atropine-reversible, accumulation of $\left[{ }^{3} \mathrm{H}\right]$ CDP-DAG in carbachol-stimulated inositol-deficient SK-N-SH neuroblastoma cells. Cells $(0.4 \mathrm{mg}$ of protein), previously cultured for 8 days in an IFCD growth medium, were prelabeled with [ $\left.{ }^{3} \mathrm{H}\right]-$ cytidine for $60 \mathrm{~min}$ in the presence of $10 \mathrm{mM} \mathrm{LiCl}$ and then treated with buffer (open circles) or $10 \mathrm{mM}$ carbachol (closed circles) for the duration of time indicated. Parallel incubations received $10 \mu \mathrm{M}$ atropine (arrow) $10 \mathrm{~min}$ after the addition of carbachol (triangles). Data shown are the means from three experiments each performed in duplicate, variance $<10 \%$. Inset: Comparison of carbachol-stimulated $\left.{ }^{3} \mathrm{H}\right] \mathrm{CDP}-\mathrm{DAG}$ formation in cells cultured in media containing inositol (open circles, data from Fig. 2) or IFCD media (this experiment; closed circles).

mals. Proponents of the inositol depletion hypothesis must then further postulate either that inositol has become depleted in an unmeasured, but behaviorally relevant, brain compartment (for example in neurons), or alternatively that there exists a PI synthase isozyme that has a higher $K_{\mathrm{m}}$ for inositol than has thus far been demonstrated, but this has not as yet been found (Imai and Gershengorn, 1987).

The experimental approach used in the present study is based on the assumption that a slowing of the phosphoinositide cycle secondary to inositol depletion will result in an accumulation of CDP-DAG, the cosubstrate, with inositol, for PI synthase. $\mathrm{Li}^{+}$produced no demonstrable effect on stimulated $\left[{ }^{3} \mathrm{H}\right]-$ CDP-DAG accumulation in SK-N-SH cells grown in standard culture media. Drummond and Raeburn (1984) had similarly reported an insensitivity of cultured $\mathrm{GH}_{3}$ pituitary cells to $\mathrm{Li}^{+}$in regard to ligandstimulated accumulation of labeled CDP-DAG. When we reduced cellular inositol levels in the neuroblastoma cells to the range of that seen in washed brain slices, the cultured cells now showed an inositolsensitive, $\mathrm{Li}^{+}$-stimulated enhancement of muscarinic receptor-stimulated accumulation of $\left[{ }^{3} \mathrm{H}\right] \mathrm{CDP}$ DAG. It is thus possible to manipulate cellular inositol as an experimental variable. The results indicate a selective effect of $\mathrm{Li}^{+}$on inositol-deficient tissues. In the case of brain slices, this is a consequence of washing in inositol-free buffer, whereas in the case of cultured cells, it is accomplished by growth on inositolfree media. It appears that much of the variation seen in different experimental preparations for the study of brain $\mathrm{Li}^{+}$effects can be explained on the basis of differences in inositol content. Adult rat brain inositol content is 3-5 $\mathrm{mM}$ (Sherman et al., 1985), and 60$80 \%$ of this is lost in brain slice preparation as reported by Sherman et al. (1986), which is confirmed in the present study. SK-N-SH neuroblastoma cells have comparably high inositol levels, but unlike brain slices, retain their inositol even after extensive washing in inositol-free buffer. The ability to concentrate and/or retain inositol in various cell lines has not been studied systematically, although it has been reported that $\mathrm{C} 6$ glioma cells maintain a higher intracellular/ extracellular inositol gradient than N1E-115 neuroblastoma cells (Glanville et al., 1989). The lowest levels of cellular inositol encountered in this study were in inositol-deprived cells that were also carbachol stimulated. The observation could be taken as support for the existence of low inositol levels in stimulated cells that then become subject to the $\mathrm{Li}^{+}$-mediated slowing of phosphoinositide turnover, as is proposed in the inositol-depletion hypothesis. It is also of interest that even when inositol is not available to SK-N-SH cells, they exhibit relatively normal growth rates. This may indicate the presence of some activity of inositol 3-phosphate synthase. This enzyme, which cyclizes glucose 6-phosphate, is thought to reside primarily in the brain capillary endothelium (Wong et al., 1987).

The observed $\mathrm{Li}^{+}$-independent, muscarinic stimulation of $\left[{ }^{3} \mathrm{H}\right] \mathrm{CDP}-\mathrm{DAG}$ formation in neuroblastoma cells grown in standard growth media is interpreted to indicate that the PI synthase of these cells is normally saturated with regard to inositol and is operating near its $V_{\max }$. This interpretation would also explain the observed ineffectiveness of added inositol in reversing the $\left[{ }^{3} \mathrm{H}\right] \mathrm{CDP}-\mathrm{DAG}$ accumulation. Alternatively, the observed stimulatory effect of the addition of carbachol alone on $\left[{ }^{3} \mathrm{H}\right] \mathrm{CDP}-\mathrm{DAG}$ accumulation in cells that had not been depleted of their inositol could indicate the presence of a "low inositol" intracellular compartment together with PI synthase. Such an explanation has been suggested as a result of kinetic studies of CDP-DAG accumulation in sciatic nerve ( $\mathrm{Zhu}$ and Eichberg, 1990). This possibility appears unlikely in the present study because coincubation of SK-NSH cells with $10 \mathrm{~m} M$ inositol did not block the stimulated accumulation of [ $\left.{ }^{3} \mathrm{H}\right] \mathrm{CDP}-\mathrm{DAG}$.

The plateau of $\left.{ }^{3} \mathrm{H}\right] \mathrm{CDP}-\mathrm{DAG}$ seen after muscarinic receptor activation in cells cultured in inositolcontaining media is interpreted to indicate the development under these conditions of a steady state in which the rate of synthesis of the liponucleotide approaches its rate of degradation. The subsequent receptor blockade by atropine then leads to reduced $\mathrm{PIP}_{2}$ breakdown, and thereby limits the availability of (stearoyl arachidonoyl) DAG for PI resynthesis. When the metabolic fate of CDP-DAG was further investigated in inositol-depleted cells, an increased rate of labeled liponucleotide formation was ob- 
served, particularly at later incubation times. This increased rate suggests a slowing of PI synthase secondary to a reduction in available inositol. The late increase then likely reflects further depletion of available inositol and arrest of PI synthase activity. Under these conditions, the loss of $\left[{ }^{3} \mathrm{H}\right] \mathrm{CDP}-\mathrm{DAG}$ seen upon addition of atropine is indicative of ongoing metabolism of CDP-DAG other than via PI synthase. For example, the liponucleotide could be metabolized to phosphatidate, either by reversal of the CDP-DAG synthase reaction or by pyrophosphorolysis (Murthy and Agranoff, 1982). Because CDP-DAG may be a limiting substrate in the phosphoinositide cycle, CDP-DAG pyrophosphatase could well serve a regulatory function. Still another possibility, the conversion of CDP-DAG to the phosphatidylglycerolipids appears improbable because these mitochondrial structural lipids turn over relatively slowly.

It is clear from the present study that varying the cellular inositol concentration can drastically alter the observed biochemical effects of $\mathrm{Li}^{+}$, and further, that the inositol content of cultured cells is more representative of intact rat brain than is that of washed rat brain slices. Because SK-N-SH cells do not survive in millimolar $\mathrm{Li}^{+}$-containing media for long periods of time, we could not explore the possible effects of $\mathrm{Li}^{+}$ that can be elicited only after several days of in vivo exposure. Although we observed no significant inositol decrease in cultured cells exposed briefly to $\mathrm{Li}^{+}$, it remains possible that exposure of the intact brain to a combination of chronic $\mathrm{Li}^{+}$and a sustained excess of phosphoinositide-linked ligands (perhaps in specific brain regions) leads to the inositol depletion that has been hypothesized to mediate the psychotherapeutic effect of $\mathrm{Li}^{+}$. The present study nevertheless underscores potential hazards in simple extrapolation of in vitro results, on the one hand, and oversimplification of mechanism, on the other, to explain the in vivo effects of $\mathrm{Li}^{+}$.

Acknowledgment: We thank Anne Heacock for cortical slice data and Stephanie McWethy for preparation of the manuscript. This work was supported by a grant from the Lucille P. Markey Charitable Trust (B.W.A.) and NIMH Training Grant MH-15794 (E.B.S.).

\section{REFERENCES}

Allison J. H. and Stewart M. A. (1971) Reduced brain inositol in lithium-treated rats. Nature 233, 267-268.

Allison J. H., Blisner M. E., Holland W. H., Hipps P. P., and Sherman W. R. (1976) Increased brain myo-inositol 1-phosphate in lithium-treated rats. Biochem. Biophys. Res. Commun. 71, 664-670.

Avissar S., Schreiber G., Danon A., and Bellmaker R. H. (1988) Lithium inhibits adrenergic and cholinergic increases in GTP binding in rat cortex. Nature 331, 440-442.

Avissar S., Murphy D. L., and Schreiber G. (1991) Magnesium reversal of lithium inhibition of $\beta$-adrenergic and muscarinic receptor coupling to $\mathrm{G}$ proteins. Biochem. Pharmacol. 412, $171-175$.
Berridge M. J., Downes C. P., and Hanley M. R. (1982) Lithium amplifies agonist-dependent phosphatidylinositol responses in brain and salivary glands. Biochem. $J$. 206, 587-595.

Bottenstein J. and Sato G. (1979) Growth of a rat neuroblastoma cell line in serum-free supplemented media. Proc. Natl. Acad. Sci. USA 76, 514-517.

Downes C. P. and Stone M. A. (1986) Lithium-induced reduction in intracellular inositol supply in cholinergically stimulated parotid gland. Biochem. J. 234, 199-204.

Drummond A. H. and Raeburn C. A. (1984) The interaction of thyrotropin-releasing hormone-stimulated lipid metabolism in $\mathrm{GH}_{3}$ pituitary tumour cells. Biochem. J. 224, 129-136.

Ebstein R. P., Hermoni M., and Belmaker R. H. (1980) The effect of lithium on noradrenaline-induced cyclic AMP accumulation in rat brain: inhibition after chronic treatment and absence of supersensitivity. J. Pharmacol. Exp. Ther. 213, 161167.

Fisher S. K. and Snider M. R. (1987) Differential receptor occupancy requirements for muscarinic cholinergic stimulation of inositol lipid hydrolysis in brain and in neuroblastomas. $\mathrm{Mol}$. Pharmacol. 32, 81-90.

Fisher S. K., Heacock A. M., and Agranoff B. W. (1992) Inositol lipids and signal transduction in the nervous system: an update. J. Neurochem. 58, 18-38.

Forn J. and Valdecasas F. G. (1971) Effects of lithium on brain adenylate cyclase activity. Biochem. Pharmacol. 20, 27732779.

Gee N. S., Reid G. G., Jackson R. G., Barnaby R. J., and Ragan C. I. (1988) Purification and properties of inositol-1,4-bisphosphatase from bovine brain. Biochem. J. 253, 777-782.

Ghalayini A. and Eichberg J. (1985) Purification of phosphatidylinositol synthetase from rat brain by CDP-diacylglycerol affinity chromatography and properties of the purified enzyme. $J$. Neurochem. 44, 175-182.

Glanville N. T., Byers D. M., Cook H. W., Spence M. W., and Palmer F. B. St. C. (1989) Differences in the metabolism of inositol and phosphoinositides by cultured cells of neuronal and glial origin. Biochim. Biophys. Acta 1004, 169-179.

Godfrey P. P. (1989) Potentiation by lithium of CMP-phosphatidate formation in carbachol-stimulated rat cerebral-cortical slices and its reversal by myo-inositol. Biochem J. 258, 621624.

Godfrey P. P., McClue S. J., White A. M., Wood A. J., and Grahame-Smith D. G. (1989) Subacute and chronic in vivo lithium treatment inhibits agonist- and sodium fluoride-stimulated inositol phosphate production in rat cortex. $J$. Neurochem. 52, 498-506.

Hallcher L. M. and Sherman W. R. (1980) The effects of lithium ion and other agents on the activity of myo-inositol-1-phosphatase from bovine brain. J. Biol. Chem. 255, 10896-10901.

Heacock A. M., Fisher S. K., and Agranoff B. W. (1987) Enhanced coupling of neonatal muscarinic receptors in rat brain to phosphoinositide turnover. $J$. Neurochem. 48, 1904-1911.

Honchar M. P., Ackermann K. E., and Sherman W. R. (1989) Chronically administered lithium alters neither myo-inositol monophosphatase activity nor phosphoinositide levels in rat brain. $J$. Neurochem. 53, 590-594.

Imai A. and Gershengorn M. C. (1987) Independent phosphatidylinositol synthesis in pituitary plasma membrane and endoplasmic reticulum. Nature 325, 726-728.

Inhorn R. C. and Majerus P. W. (1987) Inositol polyphosphate 1-phosphatase from calf brain. J. Biol. Chem. 262, 1594615952.

Kennedy E, D., Challiss R. A. J., and Nahorski S. R. (1989) Lithium reduces the accumulation of inositol polyphosphate second messengers following cholinergic stimulation of cerebral cortex slices. J. Neurochem. 53, 1652-1655.

Kennedy E. D., Challiss R. A. J., Ragan C. I., and Nahorski S. R. (1990) Reduced inositol polyphosphate accumulation and inositol supply induced by lithium in stimulated cerebral cortex slices. Biochem. J. 267, 781-786.

Mount J. N. and Laker M. F. (1981) Estimation of sugar alcohols by 
gas-liquid chromatography using a modified acetylation procedure. J. Chromatogr. 226, 191-197.

Murthy P. P. N. and Agranoff B. W. (1982) Stereospecific synthesis and enzyme studies of CDP-diacylglycerols. Biochim. Biophys. Acta 712, 473-483.

Sherman W. R., Leavitt A. L., Honchar M. P., Hallcher L. M., and Phillips B. E. (1981) Evidence that lithium alters phosphoinositide metabolism: chronic administration elevates primarily D-myo-inositol-1-phosphate in cerebral cortex of the rat. $J$. Neurochem. 36, 1947-1951.

Sherman W. R., Munsell L. Y., Gish B. G., and Honchar M. P. (1985) Effects of systemically administered lithium on phosphoinositide metabolism in rat brain, kidney, and testis. $J$. Neurochem. 44, 798-807.

Sherman W. R., Gish B. G., Honchar M. P., and Munsell L. Y. (1986) Effects of lithium on phosphoinositide metabolism in vivo. Fed. Proc. 45, 2639-2646.

Sillence D. J. and Downes C. P. (1992) Lithium treatment of affective disorders: effects of lithium on the inositol phospholipid and cyclic AMP signalling pathways. Biochim. Biophys. Acta $1138,46-52$.

Stubbs E. B. Jr., Heacock A. M., Seguin E. B., and Agranoff B. W. (1991) Lithium-independent muscarinic receptor activated accumulation of CDP-diacylglycerol in human neuroblastoma cells. Soc. Neurosci. Abstr. 17, 421.

Stubbs E. B. Jr., Walker B. A. M., Owens C. A., Ward P. A., and Agranoff B. W. (1992) FMLP-stimulates and ATP $\gamma$ S potentiates $\left[{ }^{3} \mathrm{H}\right]$ cytidine $5^{\prime}$-diphosphate-diglyceride accumulation in human neutrophils. J. Immunol. 148, 2242-2247.
Sun G. Y., Navidi M., Yoa F.-G., Lin T. N., Orth O. E., Stubbs E. B., Jr., and MacQuarrie R. A. (1992) Lithium effects on inositol phospholipids and inositol phosphates: evaluation of an in vivo model for assessing polyphosphoinositide turnover in brain. J. Neurochem. 58, 290-297.

Watson S. P., Shipman L., and Godfrey P. P. (1990) Lithium potentiates agonist formation of $\left[{ }^{3} \mathrm{H}\right] \mathrm{CDP}$-diacylglycerol in human platelets. Eur. J. Pharmacol. 188, 273-276.

Whitworth P. and Kendall D. A. (1988) Lithium selectively inhibits muscarinic receptor stimulated tetrakisphosphate accumulation in mouse cerebral cortex slices. $J$. Neurochem. 51, 258266.

Whitworth P., Heal D. J., and Kendall D. A. (1990) The effects of acute and chronic lithium treatment on pilocarpine-stimulated phosphoinositide hydrolysis in mouse brain in vivo. Br.J. Pharmacol. 101, 39-44.

Wong Y.-H. H., Kalmbach S. J., Hartman B. K., and Sherman W. R. (1987) Immunohistochemical staining and enzyme activity measurements show myo-inositol-1-phosphate synthase to be localized in the vasculature of brain. J. Neurochem. 48, 1434-1442.

Wood A. J. and Goodwin G. M. (1987) A review of the biochemical and neuropharmacological actions of lithium. Psychol. Med. 17, 579-600.

Zhu X. and Eichberg J. (1990) A myo-inositol pool utilized for phosphatidylinositol synthesis is depleted in sciatic nerve from rats with streptozotocin-induced diabetes. Proc. Natl. Acad. Sci. USA 87, 9818-9822. 